\title{
Inquiry-Based Learning in English Teaching at a Candidate School of IB PYP: Implementation and Benefits
}

\author{
Heppy Mutammimah1, Dewi Rochsantiningsih2, Abdul Asib ${ }^{3}$ \\ 1Sebelas Maret University, Surakarta, Indonesia. E-mail: el.mimah@gmail.com \\ ${ }^{2}$ Sebelas Maret University, Surakarta, Indonesia. E-mail: dewi_roch@hotmail.com \\ ${ }^{3}$ Sebelas Maret University, Surakarta, Indonesia. E-mail: abdulasib@yahoo.com
}

\section{ARTICLE INFO}

Keywords:

Inquiry-based Learning;

Teaching English;

International

Baccalaureate; PYP.

How to cite:

Mutammimah, H., et al.

(2019). Inquiry-Based

Learning in English

Teaching at a Candidate

School of IB PYP:

Implementation and

Benefits. Langkawi

Journal of the Association

for Arabic and English,

5(2), 115-126.

DOI:

http://dx.doi.org/10.31 332/lkw.v5i2.1297

\begin{abstract}
This paper aimed to investigate the implementation and the benefits of inquiry-based learning (IBL) in English teaching at the candidate school of International Baccalaureate Primary Years Programme (IB $P Y P)$ in Surakarta. Three English teachers at a candidate school of IB PYP in Surakarta were chosen purposively to participate in this study. This research employed a qualitative approach and emphasized on a case study. The techniques for collecting data comprised in-depth interviews, observation, and document analysis. The researchers analyzed the collected data through the Constant Comparative Method (CCM). The results revealed that the implementation of inquiry-based learning in English teaching in this school used Bruce and Davidson's view and some features of IBL. That cycle involved asking, investigating, creating, discussing, and reflecting. There were four benefits of this method in English teaching based on the International Baccalaureate Primary Years Programme (IB PYP). They were 1) the teachers develop meaningful activities for the students, 2) teaching and learning were student-centered, 3) the students learn through language and get endurable understanding, and 4) it promotes students 'skills and attitude at teamwork. Considering the results of this study, it implies that the implementation of inquiry-based learning in English teaching has positive effects for students and teachers.
\end{abstract}

\section{Introduction}

Living in the industrial revolution 4.0 is the challenges circumstance for the teachers and the schools providing services for helping the students reach $21^{\text {st }}$ century learning skills. So many disruptions happened in many sectors of life; economy, social and education as well. Some schools replace the old essential skill competencies and knowledge that focused on memorizing with new standards for what students should be able to do. The schools try to adopt, adapt, and use a new curriculum and method that will enable students to acquire the creative thinking, flexible problem solving, collaborative and innovative skills they will need to be successful in work and life (Center, 2010).

One of the curriculum implementations that provided features needed the school for globalization, and the current era is the International Baccalaureate Primary Years Programme. This curriculum promotes the educational framework that bringing open-mindedness in the school community and preparing students to become independent learners and inquirers. In the written curriculum, five elements 
will synergize each other involving knowledge, concepts, attitudes, skills, and action (International Baccalaureate, 2017). The teachers taught these elements to the students through an inquiry-based learning method that requires the students to construct their knowledge in their real experiences.

The inquiry classroom is far less about rote learning and memorizing fact. It is more about how the students actively involved in the teaching and learning process and get authentic and meaningful experiences. The characteristic of this method is learning stimulated by questioning, investigating, collaborative learning, problemsolving, creating solutions, applying to practical situations that emphasis on the process rather than the products and focus on student-centered rather than teachercentered (Fiore, 2016).

Prince and Felder (2006) define inquiry-based learning as an inductive process of learning. It starts from observation or complex real-world problems, then the students discuss, analyze, investigate the data, and finally generate or create the facts, procedures, and guiding principles. In another way, Fauziati (2014) mentions that inquiry-based learning is a process of seeking truth, information, or knowledge by questioning. Questions hopefully come up from the students for raising their critical thinking, but they are allowed deriving from the teachers as long as the guidance for driving the learning process.

According to Scardamalia in Irawan etl (2017), in inquiry-based learning, the teachers play an active role. They role throughout the teaching and learning process by establishing a culture where ideas are respectfully challenged, tested, redefined, and viewed as improvable, moving children from a position of wondering to position of enacted understanding and further questioning. Inquiry requires more than simply answering questions or getting answers but espouses investigation, exploration, search, quest, research, pursuit, and study. It is promoted by involvement with a community of learners, each learning from the others in social interaction.

Through inquiry-based learning, students can get valuable opportunities and experiences to improve their understanding of both language content and scientific practices. Students will collaborate to create new knowledge while learning simultaneously how to think critically and creatively through inquiry, reflection, exploration, experimentation, and trial and error. However, the implementation of inquiry learning in classrooms presents a number of significant challenges. Some schools have been exploring these challenges through a program of research on the use of scientific visualization technologies as well as inquiry-based classrooms to support inquiry-based learning in different subjects (Alameddine, 2016).

Different procedures or cycles are bringing this method in classroom practice. Kuklthau, Maniotes \& Caspri (2007) mention seven activities in the inquiry process involving investigation, exploration, search, quest, research, pursuit, and study. Bruce and Davidson (1996) view that the inquiry-based learning cycle consists of asking, investigating, creating, discussing, and reflecting. Having different ideas with previous key figures, Karplus and Their at Rejeki (2017) have three cycles, namely exploration, concept introduction, and concept application. Then, Roger Bybee shows the sequences as engagement, exploration, explanation, elaboration, and evaluation (Fauziati, 2014). Another model comes from Alberta, who divides this model into 
seven phases, including reflecting, planning, retrieving, processing, creating, sharing, and evaluating (Ismail, 2006).

Inquiry-based learning is a popular method in teaching science and society, and many kinds of research reveal the effectiveness of this method in those scopes. Even inquiry-based learning is most used to teach science and social, but it can also be implemented to teach language. Teaching language through inquiry is viewed as "Pursuing significant questions through using questions and ways of researching from a range of knowledge system" (Well, 1999). Concerning the students' social world with what they are learning helps them understand the unknown. Language inquiry attempts to get to the main of specific curricular outcomes, allowing students to have a choice in the topics they learn, the process they undertake, and how they represent their learning and new understanding (Alameddine \& Ahwal, 2016).

This paper intends to explore the implementation of inquiry-based learning and its benefits on English teaching at a candidate school of International Baccalaureate Primary Years Programme (IB PYP) in Surakarta. The researchers choose this school because this is the first school in Surakarta that implemented IB PYP curriculum and inquiry-based learning as a method in the teaching and learning process. The researchers suggest that the issue of successful implementation of inquiry-based learning on English language learning in International Baccalaureate Primary Years Programme (IB PYP) schools and benefits of it can also contribute to the border works of literature on teaching English. Moreover, it can add the references for the researcher who wants to develop this research.

\section{Method}

\subsection{Research Design}

The purposes of this research were to study the implementation of inquirybased learning in teaching English at a candidate school of International Baccalaureate Primary Years Programme (IB PYP) and to understand its benefits on teaching English. This study applied a qualitative method and focused on a case study design. A case study is a research design that focuses on the in-depth analysis of a case such as a program, an activity, event, an individual to get depth understanding of it. It engages with time and action and requires some procedures to collect the data varieties (Creswell, 2014; Yin, 2012).

The steps or procedures of conducting qualitative research are (Creswell, 2012):

a. Identifying the researcher's intent, the appropriate design, and how the purpose relates to the research problem. A case study focuses on developing an in-depth understanding of a case, such as an event here. The critical consideration is how the researcher will use the situation to understand an issue.

b. Discussing how the researcher plans to receive approval and gets access to study sites and participants.

c. Collecting appropriate data emphasizing time in the field, multiple sources of information, and collaboration. For a case study, the researcher collects as many types of data as possible to develop an in-depth understanding of a case, such as observations, interviews, and documents).

d. Analyzing and interpreting researcher data within a design

e. Writing and reporting the researcher's research consistent with the design. 


\subsection{Research Subjects}

This case study took place at a candidate school of the International Baccalaureate Primary Years Programme (IB PYP) in Surakarta. There are three English teachers. The study let in all the English teachers as participants in this research purposively. Besides that, the events of teaching and learning English using inquiry-based learning were included and observed to get substantial data and also required as complementary data.

\subsection{The techniques of Data Collection}

The researchers utilized a depth interview, observation, and document analysis to collect the data. The interview was in the form of a semi-structured interview, whereas the researchers had lists of the questions improved following the participants' answers. The observation was used to gain the data from the events concerning with inquiry-based learning in teaching English. Document analysis was used to analyze all the documents relating to the implementation of inquiry-based learning on English teaching there.

\subsection{The technique of Data Analysis}

Then, the collected data were analyzed through the Constant Comparative Method (CCM) purposed by Barney Glaser and Anselm Strauss (1967). The constant comparative method allows the researchers to think and compare the analysis of different levels and angles so that the similarities and differences in data acquisition such as interviews, field notes, and document analysis can establish a pattern (Merriam, 1998). The main feature of this method is to compare data with categories that arise trough the collection and analysis of data simultaneously. The procedures of this technique are:

1. Writing interview's transcripts, field notes, and document analysis

2. Open coding (Identifying words that appear obtained from transcripts, field note, and document analysis)

3. Categorization (naming subcategory or categories)

4. Axial coding (getting rid of the same sub-category

5. Selective coding (giving definition of the group

6. Next analysis (integrating the concept of the appropriate group (Staurus \& Corbin, 1990)

\section{Findings and Discussion}

\subsection{Finding}

The finding data here are divided into two subcategories. The first is regarding the implementation of inquiry-based learning on English teaching, and the last one concerns the benefits of it.

\subsubsection{The implementation of inquiry-based learning on English teaching}

Table 1 below shows different elements as evidence of inquiry-based learning implementation on English teaching that also implements IB PYP frameworks. T1, T2, and T3 are English teachers. From the interview, observation, and document analysis, the researchers checked for each element in the table if T1, T2, and T3 implemented it or not in the class. From the total score listed below can be seen in which the teacher applied the elements in the class. The teachers who used more 
parts reveal more evidence of effective implementation of inquiry-based learning in English teaching. Two teachers incorporated all aspects of inquiry in their education while one teacher incorporated some elements.

Table 1. Elements of inquiry-based learning in IB PYP on English teaching

\begin{tabular}{|c|c|c|c|c|c|}
\hline No & Inquiry-based learning elements in IB PYP & T1 & T2 & T3 & Total \\
\hline 1 & Learners as inquirers, teachers as facilitators & $\sqrt{ }$ & - & $\sqrt{ }$ & 2 \\
\hline 2 & $\begin{array}{l}\text { Learning through meaningful problems in } \\
\text { real situations }\end{array}$ & $\sqrt{ }$ & $\sqrt{ }$ & $\sqrt{ }$ & 3 \\
\hline 3 & Using discourse in communication & $\sqrt{ }$ & $\sqrt{ }$ & $\sqrt{ }$ & 3 \\
\hline 4 & $\begin{array}{l}\text { Having different teaching material and } \\
\text { sources }\end{array}$ & $\sqrt{ }$ & - & $\sqrt{ }$ & 2 \\
\hline \multirow[t]{4}{*}{5} & Using inquiry cycles/ process & & & & \\
\hline & Bruce and Davidson cycles & $\sqrt{ }$ & $\sqrt{ }$ & $\sqrt{ }$ & 3 \\
\hline & Roger Bybee View & - & - & - & \\
\hline & Karplus and Their & - & - & - & \\
\hline 6 & Rotation in different formative assessments & $\sqrt{ }$ & $\sqrt{ }$ & $\sqrt{ }$ & 3 \\
\hline 7 & Rotation in various summative assessments & $\sqrt{ }$ & $\sqrt{ }$ & $\sqrt{ }$ & 3 \\
\hline 8 & Assessing four tracks in English scope & $\sqrt{ }$ & $\sqrt{ }$ & $\sqrt{ }$ & 3 \\
\hline \multicolumn{2}{|c|}{ Total } & 8 & 6 & 8 & \\
\hline
\end{tabular}

\subsubsection{The benefits of inquiry-based learning on English teaching}

Concerning the benefits gotten from the inquiry, T1 stated that this method created meaningful activities for students. Through inquiry-based learning, the students directly can get relevant experiences that are relevant to their real circumstances. They try to solve the problems and finish some projects. Moreover, students look more active in engaging the teaching and learning process. They created posters, drama, articles, and also performed in front of the class, presenting the result of their project. The other view gotten from T2's interview; she also explained that her students were more active and looked like more enthusiasts following the learning process.

In another interview, T3 explained that inquiry-based learning required students-centered. Furthermore, in his class, the students sometimes choose and requested their material. It was allowed, whereas the selected content by the students still on the track with Unit of Inquiry (lesson plan) and Program of Inquiry (Syllabus). Additionally, from the conducted observations, T3's students engaged actively in teaching and learning. They free asking questions concerning the lesson and try constructing their knowledge.

Furthermore, the gotten data from observation in all class's T1, T2, and T3 revealed that English is dominantly used as the instructional language in English lessons even they still used their mother tongue. It trains students to communicate in English that will help them to understand materials in other experiences, also using English as the instructional language. Starting now, it means that the students learn through language that they used in their daily communication in the class as resources for thinking and reasoning. Based on this model of learning that uses language as a tool for learning and connecting to the world, the students can learn a 
different culture, integrate culture, and combine it with their own culture. This condition will touch the students' personal experiences because they are involved, feel connected, and knowledgeable. Finally, as a result, the students remember more and longer what they learned.

The inquiry-based learning class is noisy, but they are noise in discussing the lesson in groups. Most class activities were in pair and the group even it was not held every day. Through teamwork and group, the students learned to interact with others, to develop their personality and social communication, and to solve the problem together. Moreover, this technique also helped the student to fulfill the weakness member by the strength of others. In teamwork and group, they also learn how to respect their friends an idea, how to manage themselves in communication and social interaction, and how to think critically solve the problems. The teacher's role here is promoting students' skills and reminding the students behaving in teamwork without leaving the attitudes.

\subsection{Discussion}

Based on the finding data, there are two points here that could be discussed as follow:

\subsubsection{The implementation of inquiry-based learning on English teaching}

The main feature of inquiry-based learning is the inquiry process, whereas the students become inquirers. T1 and T3 dominantly as facilitators allow their students to discover and inquire about their new knowledge. They did not much give instruction and always drive the students. T2 also let her students be inquirers but in the tiniest portion. She stated that it happened because she taught the small grades in the school. The students need adaptation and instruction, rising higher levels as inquiries. The students and the teachers' role as inquirers and facilitators here are in line with Savage and Armstrong's ideas (1996). They explained that inquiry learning is a form of training for producing knowledge. In contrast, the students are required to inquiry and create a conclusion based on their consideration and experiences they find themselves. This finding is also in line with the principle declared by Brooks and Brooks (1993) at Fauziati (2014). The based policy for inquiry-based learning is the students taking the initiative and autonomy in the classroom. The teachers' roles in teaching and learning are to guide and facilitate the students constructing the knowledge.

All the teachers here created the learning activities around solving problems, designing, and producing some projects in their real situations. Most of the events went inductively. The students tried to investigate and discuss some issues, and in the end, they presented their conclusion that would be gotten feedback from the teacher. The process of communication is not only in the form of question and answer but dialogue to find the solution to the problems that created discourse. In the inquiry-based learning class, communication in the classroom is characterized by discourse. Two ways communication is more effective and appropriate to describe and learn this situation (Prince, M. J., and R. M. Felder Prince, 2006)

Related with the material chosen in the teaching and learning, T1 and T3 had a variety of instructional material. They took the content not only from the books, but also from the internet and had different types of material such as written, audio, and 
video. T2 had limitations in getting sources of the instructional material. She tended to use the handbook and use the audio and video provided from the guide book to support the content. The different learning materials and sources that they are conducting are a requirement from the International Baccalaureate Organization (2007). IBO does not limit the instructional material and source, so the teachers free enough to select and choose the material under the umbrella of the transdisciplinary theme. This finding is also similar to Setyawan's research (2017). The result of his study showed that the teachers had many sources for a different material that would be taught to the students. The teachers were allowed to use everything around them as instructional material and references of the current theme they were discussing (Fauziati, 2014; Prince and Felder, 2006; Brooks and Brooks, 1996). The finding in this study is also under Savage's work (2016), showing that the teachers could work flexible and transportable for material and classroom schedules. It means that the teachers were allowed to decide where they will choose the material engaging with the transdisciplinary themes.

Regarding the procedure of inquiry-based learning, all the teachers applied Bruce and Davidson's cycle (1996). The sequences of inquiry-based learning by Bruce and Davidson were implemented in all items on it. They used asking, investigating, creating, discussing, and reflecting. The procedures can be seen in figure 1. Ideally, the students ask the questions deriving the classroom activities, but the teachers permitted asking the subject intended to guide them. They only provided them with the appropriate actions to help them in constructing knowledge. Based on the question, they investigate the issues to derive the new theory through browsing the internet, reading articles, or discussing with others. Next, they create something based on the topic while try, experiment, draw, explain, and discuss it. The last one, they present their results to get some reflection and feedback from other groups or teachers to get the better one (Rejeki, 2017).

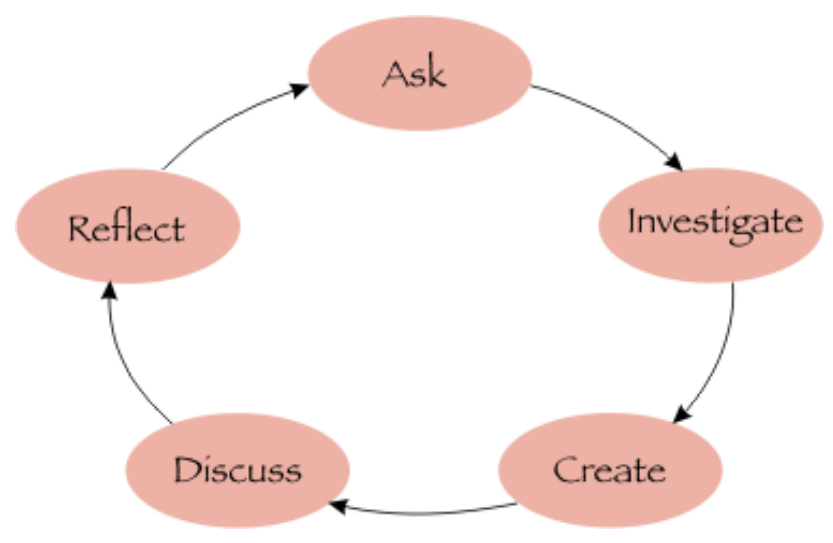

Figure 1 Cycle of inquiry (Bruce and Davidson)

The procedures of inquiry-based learning are various. Besides Bruce and Davidson's cycle, there is Karplus \& Their's learning cycle, including exploration, concept introduction, and concept application. Other comes from Bybee's learning cycles that cover five steps; they are engagement, exploration, explanation, elaboration, and evaluation. Curriculum 2013, under the new term scientific approach also required inquiry-based learning as a teaching method. The cycles are 
observing, questioning, collecting information or experimenting, associating, or information processing, and communicating (Fauziati, 2014). In this research, the participants tend to use Bruce and Davidson's cycle because it more appropriate procedure than others to teach English material from Cambridge University.

The teacher utilized formative and summative assessment in teaching and learning evaluation. The teachers use a checklist, rubrics, records, continuum, and exemplars as assessment tools. The assessment strategies used by the teachers are observation, performance assessments, portfolio, open-ended task, and processfocused assessment. And at the end of units, they stage the exhibition as students' demonstration from what they have learned during the PYP teaching and learning. This similar finding was revealed in Purnomo's work (2015). He found the assessment types consisting of formative and summative assessment, varieties strategies, and tools for assessing the students' performance in the International Baccalaureate Primary Years Programme (IB PYP) School at Surabaya that implementing inquiry-based learning also. These research findings refer to the fundamental principle that assessment in inquiry-based learning divided into three types; diagnostic assessment, formative assessment, and summative assessment (Alberta, 2004).

In the International Baccalaureate Primary Years Programme (IB PYP), there are four strands in the language scopes and sequences; oral language that consists of listening and speaking, visual language involving viewing and presenting, written language through reading and written language on writing. The teachers sometimes assessed one activity directly for one or more strands. For example, in the presenting section, the teachers can determine both oral and visual language that consists of listening, speaking, viewing, and presenting. This finding refers to the standardization of the International Baccalaureate Primary Years Programme (IB PYP) concerning the language scopes and sequences (International Baccalaureate, 2009).

\subsubsection{The benefits of inquiry-based learning on English teaching}

The first benefit shown from inquiry-based learning is the students getting meaningful activities in their real situation, such as relevant experiences and problem-solving activities. This finding relates to Fiore's result study (2016) that showed the students who learned through inquiry felt they were using and applying the language they learned to real activities or circumstances. In this way, they felt a sense of achievement that made them more motivated learning a foreign language and went forward in their language learning. The created meaningful activities were based on constructivism Jean Piaget (1955), Vygotsky (1978), and Brunner (1983). They purposed that 'the learners must actively construct their knowledge and skills through their experiences and interaction with the environment.'

The second benefit of this method is the English teaching and learning process held in student-centered. It means that the students actively engage and join the teaching and learning. Related with this finding, Lee (2014) stated that this method helped the students who are learning language stay active and dynamic, which in turn keeps them engaged and attentive. This finding is also strengthened with International Baccalaureate Primary Years Programme (IB PYP) characteristic, where 
inquiry-based learning is student-centered that the students' participation and involvement are fundamental (Fiore, 2016; Purnomo, 2015).

Furthermore, the gotten benefit from inquiry-based learning is the students learn through language and get endurable understanding. Lee (2014) mentioned this benefit in his study. Moreover, following this finding, IBO ( 2009) explained that 'Effective language teaching and learning are social acts, dependent on relationships with others, with context, with the environment, with the world, and with the self. Exposure to and experience with languages, with all their richness and diversity, creates an inquisitiveness about life and learning, and confidence about creating new social interactions. The language provides a vehicle for learners to engage with the world.' This data also referred to Halliday (1980), who argues that there are three ways of thinking about the relationship between learning and language, and one of them is learning through literature. In contrast, the learners use language as a tool to listen, think, discuss, and reflect on information, ideas, and issues. They learn about the world as they do so; for instance, by acquiring the word 'hail', they come to learn that there is such a concept (possibly even before having experienced it in the real world), and that is different from both snow and rain.

The last benefit of inquiry-based learning in this study is this method promoting students' skills and attitude at teamwork. This benefit is supported by Setyawan's research (2017) and Sunannengsih (2015) that explained the framework of IB PYP that provided every student with the right and opportunity to be involved in the actions either individually or in groups. Through this action, especially in a group, it is expected that students can develop themselves both individually and socially, develop their cooperative, problem-solving, conflict-resolution, as well as creative and critical thinking skills. Related to this finding, Kuhlthau on Nurtalina (2013) stated that inquiry-based learning had benefits for students. Through inquirybased learning, the students construct their learning, gain independence in research and learning, have a high level of motivation and engagement, and learn strategies and skills transferable to other inquiry projects. Moreover, it develops students' social, language, and reading skills.

Considering the results of this study drawn above, it implies that the implementation of inquiry-based learning brings positive effects for students and teachers. The teachers are active and motivated in creating the teaching and learning plan. Then the students are actively engaged in the teaching and learning process.

\section{Conclusion}

This paper has given a brief understanding of the inquiry-based learning implementation in English teaching at Candidate school International Baccalaureate Primary Years Programme (IB PYP) and the benefits of it. Even inquiry-based learning was famous for teaching science and social, but it also can be implemented for teaching English. The implementation of this method in English teaching corporate some features and used Bruce and Davidson cycles. Further, the benefits of inquiry-based learning here 1) the teachers can create meaningful activities for the students, 2) teaching and learning were student-centered, 3) the students learn through language and get endurable understanding, and 4) it promotes students 'skills and attitude at teamwork. Each feature or element and the benefits of inquirybased learning explored here hopefully can be used as considerations for teachers 
and others to apply proper implementation of it not only in science and social but also in English teaching.

The researchers realize that this paper is still far from being perfect. It just focused on the implementation and benefit of inquiry-based learning on English teaching at a candidate school of the International Baccalaureate Primary Years Programme (IB PYP). Finally, the researchers hope that other researchers can develop the issue concerning this case, mainly on the challenges, problems, and solutions in implementing inquiry-based learning at IB PYP schools.

\section{Acknowledgments}

Thanks to Miss Yanti, Miss Ima, and Mr. Tio for the participation in this study and Mr. Qoshid for advice and support finishing this research.

\section{References}

Alameddine, Mira M \& Ahwal, Hala W. (2016). Inquiry-Based Learning in the Literature Classroom. International Conference on Teaching and Learning English as an Additional Language. Social and Behavioral Science 232 (2016), 332-337.

Alberta, L. (2004). Focus on inquiry: a teacher's guide to implementing inquiry-based learning. Alberta: Learning Resource Center. Retrieved February 10, 2019, from http:// www.learning.gov.ab.ca/k12/curriculum\%0A/bySubject/focusoninquir y.pdf.

Brooks, J. G. \& Brooks, M. G. (1993). In Search of Understanding: The Case for Constructivist Classroom. Alexandria FA: Association of Supervision and Curriculum Development.

Bruce, B. C., \& Davidson, J. (1996). An Inquiry Model for Literacy across the Curriculum. Journal of Curriculum Studies, 28(3), 281-300.

Bruner, J. (1983). Child's Talk: Learning to Use Language. Oxford: Oxford University Press.

Center, P. P. R. (2010). 21st Century Skills for Students and Teachers. Honolulu: Kamehameha Schools, Research \& Evaluation Division.Research \& Evaluation Division.

Creswell, J. W. (2014). Research Design Qualitative, Quantitative, and Mixed Methods Approaches. California: Sage Publishing.

Cresswell, J.W. (2012). Educational Research: Planning, conducting, and evaluating quantitative and qualitative research. Boston: Pearson.

Fauziati, E. (2014). Methods of Teaching English as a Foreign Language (TEFL): Traditional Method Designer Methods Communicative Methods Scientific Approach. Surakarta: Era Pustaka Utama.

Fiore, E. D. (2016). Implementation of Inquiry-based Learning into Chinese as a Foreign Language Classes in International IB PYP Schools of Hong Kong.

Glaser, Barney G. \& Straus, A. (1967). The Discovery of Grounded Theory; Strategies for Qualitative Research. London UK: Aldine Transaction. 
Halliday, M. (1980). Three aspects of children's language development: Learning language, learning through language, learning about language". In Goodman, Y, Haussler, MH, and Strickland, D (eds). Oral and Written Language Development Research. Urbana, Illinois, USA: National Council of Teachers of English.

International Baccalaureate. (n.d.). What is an IB education? In 2017. Switzerland: International Baccalaureate Organization (UK) Ltd.

International Baccalaureate. (2009). Primary Years Programme Language Scope and Sequence Handbook.

Irawan, Yogi, Syahrial, \& Sofyan Dedi. (2017). The Effect of Using Inquiry-Based Learning Strategy on Students Speaking Ability ( a Case Study at SMAN 7 Bengkulu Selatan). JOALL (Journal of Applied Linguistics and Literature), 3 (2), 5979).

Ismail, Noriah. (2006). Inquiry-based learning; A New Approach to Classroom Learning. English Language Journal, 2 (1), 13- 24.

Kuhlthau, Carol C., Leslie K. Maniotes, A. K. C. (2007). Guided Inquiry: Learning in the 21st Century. Santa Barbara, California: Greenwood Publishing Group.

Lee, H. (2014). Inquiry-based Teaching in Second and Foreign Language Pedagogy. 5(6), 1236-1244. https:/ / doi.org/10.4304/jltr.5.6.1236-1244

Nurtalina. (2013). The Effect of Using Inquiry-Based Learning Strategy in the Writing Ability of the Eighth Grade Students of SMP Negeri 1 Prambanan Klaten in the Academic Year of 2012/2013. Unpublished Thesis. English Education Department State University of Yogyakarta

Organization I. B. (2007). Making the PYP happen: A curriculum framework for international primary education. Wiltshire: Antony Rowe Ltd.

Piaget, J. (1955). The Language and Thought of the Child. Ohio: World Publishing Company.

Prince, M. J., and R. M. FelderPrince, M. J., and R. M. F. (2006). Inductive Teaching and Learning Methods: Definitions, Comparisons, and Research Bases. Journal of Engineering Education, 95(2), 123-138.

Purnomo, C. H. (2015). Manajemen Pembelajaran Kurikulum International Baccalaureate Primary Years Programme di SD Ciputra Surabaya. Scientific Journal, 2(5), 255.

Rejeki, S. (2017). Inquiry-based Language Learning (Ibll): Theoretical and Practical Views in the English Classroom. English Franca, 01(02), 135-148.

Savage, Tom V. dan Armstrong, D. G. (1996). Effective Teaching in Elementary Social Studies (third edition). New Jersey (US): Prentice-Hall.

Savage, M. J. \& S. M. D. (2016). Living Transdisciplinarycurriculum: Teachers' Experiences with the International Baccalaureate's Primary Years Programme. International Electronic Journal of Elementary Education, 9(01), 1-20. 
Setyawan, T. Y. (2017). Primary School Pre-Service Teachers' Perspectives on the Primary Years Program and Its Implementation. International Journal of Indonesian Education and Teaching (IJIET), 1(2), 194-205.

Strauss, A \& Corbin, J. (1998). Basics of Qualitative Research: Techniques and Procedures for Developing grounded theory. Sage Publications. Thousand Oaks. London.

Sunaengsih, C. (2015). Pengaruh Model Pembelajaran Transdisciplinary terhadap Karakter Siswa pada Sekolah Internasional Berbasis International Baccalaureate. Mimbar Sekolah Dasar, 2(02), 170-177.

Vygotsky. (1978). Mind in Society. Cambridge, MA: Harvard University Press.

Yin, R. K. (2012). Applications of case study research (Third). Thousand Oaks, CA: Sage Publishing. 